\title{
Effect of pollution on the benthos off Gothenburg
}

\author{
PaAvo Tulkki \\ University of Turku, Turku, Finland
}

\begin{abstract}
KURZFASSUNG: Die Wirlkung der Wasserverunreinigungen auf das Benthos vor Göteborg. Die Mündung des Flusses Göta älv stellt hinsichtlich seiner morphologischen, hydrographischen und teilweise seiner biologischen Eigenschaften ein typisches Astuar dar. Da der Strom durch die Stadt fließst, ist das Wasser durch die Kloakenwässer und Industrieabwässer verunreinigt. Die Salinität beträgt 1 bis $15 \%$ innerhalb Göteborgs und 15 bis $30 \%$ außerhalb der Flußmündung im Hake Fjord. Die Bodenfauna setzt sich aus marinen und Brackwassertieren zusammen. Bei einem Vergleich dieser Fauna mit der von reinen Böden an der schwedischen Westküste lassen sich einige Besonderheiten feststellen. In dem Fluß bei Göteborg finden sich nur wenige Tierarten, doch treten einige von diesen in äußerst dichten Populationen auf. $\mathrm{Zu}$ diesen Arten gehören beispielsweise Capitella capitata $\left(56000 \mathrm{Tiere} / \mathrm{m}^{2}\right)$, Polydora ciliata (7250 Tiere $/ \mathrm{m}^{2}$ ) und Nematoden (über 400000 Tiere $/ \mathrm{m}^{2}$ ). Capitella und Polydora sind, wenn sie massenhaft vorkommen, kosmopolitische Indikatoren verunreinigten Meerwassers. Das Auftreten des Harpacticiden Paramphiascopsis longirostris, der im Hafengebiet in großer Individuenzahl gefunden wurde, war bisher noch nicht beobadtet worden. Außerhalb der Stadt wandelt sich das Erscheinungsbild der Bodenfauna und gleicht sich zunehmend dem normaler Populationen an, doch kann noch an den äußersten Untersuchungsstellen (4 bis 5 Seemeilen außerhalb der Stadt) ein Einfluß der Abwässer auf die Bodenfauna nachgewiesen werden. Anhand einiger älterer faunistischer Beobachtungen ließen sich die Veränderungen der Bodenfauna im Hafengebiet rekonstruieren. Von etwa 1900 bis 1965 ist die Fauna zunehmend artenärmer geworden; einige Arten sind völlig verschwunden, während andere sich von der Flußmündung nach außerhalb zurückgezogen haben. Die größten Veränderungen hat die Bodenfauna in den Jahren 1920 bis 1930 erfahren.
\end{abstract}

\section{INTRODUCTION}

All the Nordic capitals have problems of pollution in their coastal waters. In the Oslo fjord, for example, the stretch from Dröback to Oslo is seriously polluted (Föyn 1960). The situation at Copenhagen seems to be more favourable, for there the relatively strong currents cause better ventilation of the bottoms. The third largest town in the Kattegat-Skagerrak region is Gothenburg at the mouth of the Göta älv. The literature dealing with this region is very limited, particularly in regard to biological investigations. At the Gothenburg Museum of Natural History there is, however, a considerable amount of material including reports of studies made at different times by members of the museum staff.

In November 1964, and January and July 1965, a group including Dr. A. Eliasson, Mr P. BAgge, mag. phil., and myself under the leadership of Dr. B. Swed- 
MARK (Kristineberg Zoological Station) studied the quality of the bottom fauna in the lower reaches of the Göta älv, and in the estuary region as far as the Dana fjord. This paper is a preliminary report of a larger study, which will be published at a later date.

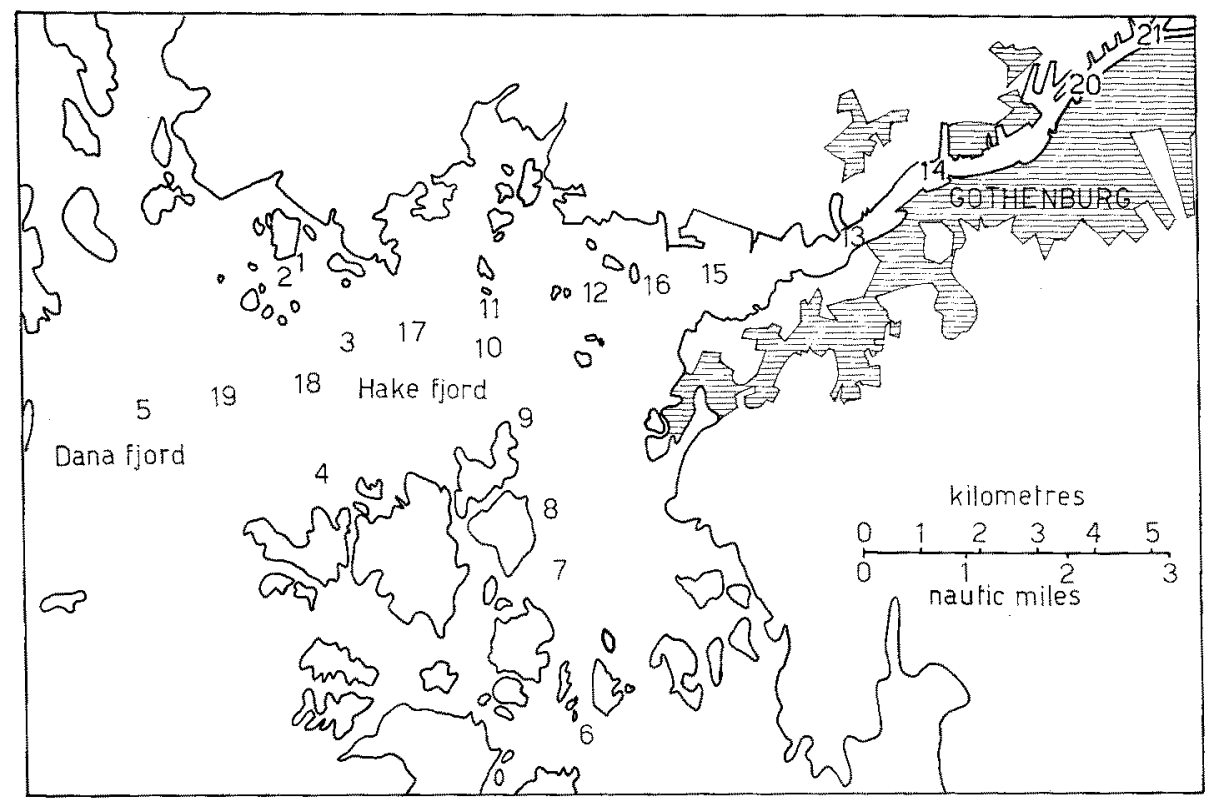

Fig. 1: Study area with sampling localities

\section{TOPOGRAPHY AND HYDROGRAPHY OF THE RIVER MOUTH}

The south branch of the mouth of the river Göta älv runs through Gothenburg, and widens into a funnel-shaped estuary west of the city. The depth, which is approximately $7 \mathrm{~m}$ in the city of Gothenburg increases successively as one approaches the mouth of the river to $12 \mathrm{~m}$. The $20 \mathrm{~m}$ isobath is situated 2 nautical miles of the river mouth, and a depth of $30 \mathrm{~m}$ is found in the Dana fjord, which runs in a northwesterly direction off the estuary. The morphometrical features of the estuary (funnel-shape, increasing depth of water outward, no threshold) are such as to allow quite an effective turnover of water. According to hydrographic data the region is a typical estuary with an outflowing surface current of river water which induces an inflowing gradient current of bottom water of higher salinity.

The harbour area is characterized by great variations in salinity $(0$ to $15 \%$, particularly in the surface water. In the outermost parts of the study area the salinity varies between 22 and $30 \%$. The measurements of oxygen made in the present investigation gave rather high oxygen values at all depths, but especially in the fresher surface water, where saturation values of 100 per cent were found. The highest 
values of $\mathrm{BOD}$ and $\mathrm{KMnO}_{4}$ consumption in the river water were observed at stations 20 and 21. They then decreased with distance from the river mouth. At a station in the Dana fjord, about the same oxygen consumption was found both in surface and bottom water, which implies that the oxygen-consuming sewage has become greatly diluted at this distance from the town (Fig. 1).

\section{CHANGES IN THE BOTTOM FAUNA DURING THE PRESENT CENTURY IN THE AREA INVESTIGATED}

The documents at the Gothenburg Museum of Natural History dealing with the fauna make it possible to reconstruct the composition of the fauna in the investigation area since 1922 and, for some localities, since 1912.

A survey of the distribution of some common and representative species shows a tendency towards faunal regression in a westerly direction. Species which formerly lived in the lower reaches of the river have now their distribution area nearer the mouth of the river. At a locality near the Hisinge Bridge in the city there were thirteen marine euryhaline species in 1922. In 1938 there were only two polychaetes, Eteone longa and Nereis diversicolor, both in large populations. The records made in 1946 give Nereis diversicolor and Crangon crangon as well as nematodes and oligochaetes, which all can tolerate low oxygen content and low salinities. During the most recent investigation, in 1965, only two oligochaetes were found at that locality. The bottom material consisted of black ooze, smelling sulphur, with bacterial threads.

At station 14, about 1.5 nautical miles downstream from station 20 , a decline in the marine components of the bottom fauna has also been observed. In 1912, there were fourteen marine benthic species and three littoral forms there. The list made in 1922 reported nine species, six of which had been observed earlier, while Nereis diversicolor, oligochaetes and nematodes had not been reported there previously; as far as the last two are concerned, they may have been overlooked. The changes in the fauna that have occurred during the interval of twenty-four years suggest a greater inflow of sewage and possibly a reduction in the salinity. Some changes took place from 1946 to 1965; among others Abra alba, which had not been observed since 1922, was found. Nucula nitida, never found so far up the river before, is now living there, and the macroscopic bottom fauna comprises eight species. Contrary to older investigations, we also took the meiobenthos into consideration. Among the components found in samples taken with the core sampler at station 14, Paramphiascopsis longirostris, a harpacticoid copepod, a typical species of polluted places in the estuary of the river Göta älv, is worthy of mention. There was a meiobenthos rich in individuals at station 14 in the top 5 to $6 \mathrm{~cm}$ of the surface layer of the bottom sediment.

At station 13, which is situated downstream from station 14 , but which still belongs to the polluted harbour area, we found, that the number of marine benthic species has increased during the present century. There were two species in 1922, eleven in 1938, twenty in 1946, and twenty-seven species in 1965. Among the species that have appeared successively are Mya arenaria, Cardium lamarcki, Corophium volutator and Paramphiascopsis longirostris. Capitella capitata occurred in great 
numbers in 1922, which suggests that there was pollution there even then, but among the new species are those which are usually associated with pollution.

The regression in the marine bottom fauna in the lower reaches of the river Göta älv revealed by the investigation, and the reduction of the coastal fauna that has occurred in the region beyond the mouth of the river, are clearly selective. The varying susceptibility of the organisms to and resistance against environmental changes are clearly manifested in the region studied. If we are concerned with their reactions to the ecological changes caused by water pollution, the species may be divided into different groups:

(1) Regressive species, which have retreated westwards or disappeared completely from the region. Among these are Nephtys hombergi, Eteone longa, Lagis koreni, Diastylis rathkei, Mya arenaria and most sponges, echinoderms and ascidians. One of the species that has completely disappeared is Halicryptus spinulosus.

(2) Transgressive species, which have spread in the direction of the polluted regions, or which now occur in the investigation area without being found there earlier. This group includes the isopods Cyatbura carinata and Idotea cbelipes, which are not really benthic forms and which now occur on a very polluted dredged bottom. Also Nucula nitida belongs to this group.

(3) Indifferent species, whose distribution in the region has not changed since 1922. Examples of such species are Harmotboë imbricata, Cardium lamarcki, Mya arenaria and Corbula gibba.

\section{BOTTOM ANIMAL COMMUNITIES OF THE GOOTA ALV ESTUARY}

When characterizing the animal communities on the soft bottoms of the region, we started from the associations defined by Molander $(1928,1962)$ in the neighbouring regions on central Bohuslän coast. In view of the general character of the animal communities, we have divided the investigation region into three sub-regions.

$\mathrm{Sub}-\mathrm{region} 1$ : The outermost part of the investigation area. The bottom fauna is in rather good agreement with MOLANDER's Echinocardium - filiformis community. According to MOLANDER this community occurs generally in the inner parts of the fjords on the west coast of Sweden. It is clear, that pollution in the river water affects even this sub-region, which is situted 4 to 5 nautic miles from the mouth of the river. Thus there is a rather great biomass with a rich occurrence of Nucula nitida and Nephtys incisa, which we consider to be a consequence of excess nutriment in the bottom sediment or the layers of water close to the bottom. At the same time, we observed, in comparison with MolANDER's $E$. filiformis community, a striking insufficiency of species. We were justified in exacting to find, if the area investigated had been less affected by pollution, a more regular occurrence of such species as Polyphysia crassa, Lumbrinereis fragilis, Cardium minimum and Opbiura texturata. Both Polyphysia crassa and Lumbrinereis fragilis were found in the Dana fjord in 1946.

Sub-region 2: The central part of the investigation area. The bottom fauna in this sub-region is similar to MOLANDER's Nepbtys-nitida community, although the 
following components, given by MOLANDER as typical, are lacking: Rhodine gracilior, Turitella communis, Pontoporeia femorata and Opbiura texturata. Some of these species were found here a few decades ago however. We found in this region an unexpectedly high number of individuals in comparison with Molander's account. It seems that the increased amount of detritus and nutriment is responsible for the changes in the natural chains of nutriment which can affect the balance of nature in the benthic populations.

Sub-region 3: The lower reaches of the Göta älv and the mouth area. The animal communities found there cannot be compared with Molander's communities. The bottom sediment in the area consists mainly of dark, soft silt with a great deal of organic matter, usually smelling of hydrogen sulphide, but often with a thin, pale grey oxidized surface layer. According to JeRLov (1953), the particle content of the water is greatest in this area.

There is a surprisingly great number of species on these sediments smelling of hydrogen sulphide in the lower reaches of the river Göta älv. Most numerous is Capitella capitata (>30000 specimens/sq.m.). This species, which is most numerous in regions receiving sewage (ReIsH 1963), has been found in the harbour since 1922. Among other polychaetes, Nereis diversicolor is common at several stations in the harbour area. This observation is in agreement with observations made at Turku and Helsinki (TuLKKI 1964, LAAKso 1965), where it was found that only fully grown individuals can survive on highly contaminated bottoms.

A mass occurrence of Polydora ciliata was found at stations 13 and 14 in the harbour (7250 and 840 specimens/sq.m. respectively). The species was not found outside this area. It has been observed in the harbour of Copenhagen (SMIDT 1944, ELIASSON 1962) and occurs in great numbers in the harbour of Bergen (NAIR 1962). According to BARNARD (1958), the species is a biological indicator of pollution in harbour areas.

Scolelepis fuliginosa occurs at the same stations in the harbour as Polydora. In the Gullmar fjord the species is one of the most common bottom animals on the most seriously polluted bottoms (BAGGE, verbal communication). The species seems to have the same eurybionthic features as Polydora ciliata, and can even be called a biological indicator of pollution.

Mya arenaria even occurs at station 13 in the harbour of Gothenburg (1135 specimens/sq.m.; biomass $549 \mathrm{~g} / \mathrm{sq} . \mathrm{m}$.). It is known from several polluted estuaries and coastal waters (cf. Blegvad 1932, Hynes 1963, Henriksson 1967). The species is reported from the harbour of Turku, in areas where the concentration of $\mathrm{NH}_{4}$ in the water amounts to $0.1-0.3 \mathrm{mg} / 1$ (Tulk Kr 1964). Henriksson (1967) found close relationship between the occurrence of Mya arenaria and bacterial contamination in the Sound (coefficient of correlation $=0.806$ ).

Sub-region 4 (bottom of the river upstreams of the Fiskhamn harbour): Here the bottoms consist of black sediments smelling strongly of hydrogen sulphide, and containing sewage fungi and bacteria threads. Salinity varies greatly in the bottom layers of the water, which prevents the invasion of marine benthic species. No bottom animals occur at present, but a juvenile specimen of Nereis diversicolor was found in a sample taken in 1965. 


\section{MEIOBENTHOS}

When the quantitative distribution in the area is under consideration the same observation can be made for the meiobenthos as for the macrofauna, namely that the number of organisms is greatest in the region between stations 14 (Fiskhamnen) and 16 (SE of Alvsborg). Maximal density of individuals was found at station 15, where over 670000 individuals/sq.m. were counted.

The bottom sediment at these localities has a well-defined pale oxidized surface layer on darker clay smelling of $\mathrm{H}_{2} \mathrm{~S}$. In the pale surface layer of a sediment core, hundreds of holes made by polychaetes can be seen down to 4 to $5 \mathrm{~cm}$ below the surface. Generally speaking, the organisms are bound to this surface stratum, and their vertical distribution is therefore dependent on the thickness of the oxidized layer. At stations 10,20 and 21 , where this oxidized layer is very thin, the microfauna is also weakly developed.

The maximal frequency of Nematoda in the present material was observed in July at station 14 (>400000 individuals/sq.m.). They seem to be more frequent in polluted than in unpolluted areas. The greatest depths at which they were found were $3 \mathrm{~cm}$ (January) and $5 \mathrm{~cm}$ (July) below the surface of the sediment.

Among the polychaetes in the sediment cores, Capitella capitata and Polydora ciliata were dominant. The maximal frequency of Capitella was found at station 14 ( 56000 individuals/sq.m.). Most individuals were in the oxidized surface layer, at 0-2 cm, but several individuals were found as far as $5 \mathrm{~cm}$ below the surface of the sediment. Polydora ciliata was found at the same places as Capitella, but no deeper than 3 to $4 \mathrm{~cm}$. in the sediment cores. They were found at maximal density at station 15, where over 648000 individuals/sq.m. were counted. In July 1965, Paramphiascopsis longirostris was the dominant species at the polluted localities (stations 13 and 15).

\section{SUMMARY}

1. Bottom fauna in the mouth of the river Göta älv and its estuary was studied.

2. The river bottom in the city of Gothenburg and the bottoms of the harbour area and the river mouth are strongly polluted. The pollution has dispersed almost 4 to 5 nautic miles outside that area.

3. There are no bottom animals in the river bottom by the town.

4. In the oxidized surface layer of the sediments in the harbour area some species have mass occurrences.

5. In the same places the biomass reaches its maximum.

6. Pollution has a diminishing effect on the number of species at outer localities.

7. Species which favour polluted areas are e. g. Capitella capitata, Polydora ciliata, Nereis diversicolor, Macoma baltica, Mya arenaria, Paramphiascopsis longirostris (Harpacticoida) and Nematoda spp.

8. The history of the developing pollution can be followed by the aid of old faunistic observations and material stored by the Gothenburg Museum of Natural History. 
Acknowledgements: Acknowledgements are due to the Director of the Kristineberg Zoological Station, Dr. B. SWEDMARK for making this study possible and for leading the studying group which includes Dr. A. Eliasson, Gothenburg, Museum of Natural History and Mr. P. BAgge, Kristineberg Zoological Station, A very notable contribution was made by Dr. J.P. J. WeLLs, who has determined and counted the copepods of our material.

\section{LITER ATURE CITED}

BarNard, J. L., 1958. Amphipod crustaceans as fouling organisms in Los Angeles-Long Beach harbours, with reference to the influence of seawater turbidity. Calif. Fish Game 44, $161-170$.

Blegvad, H., 1932. Investigations of the bottom fauna at outfalls of drains in the Sound. Rep. Dan. biol. Stn 37, 1-20.

Eliasson, A., 1962. Weitere Untersuchungen über die Polychaetenfauna des Oresunds. Undersökningar över Oresund. 41. Acta Univ. Lund. (Afd. 2) 58 (9), 1-97.

HeNRIKsson, R., 1967. Föroreningens inverkan på bottenfaunan i Oresund. Oresunds vandkomiteens undersøgelser 1959-1964. København, 205 pp.

Hynes, H. B. N., 1963. The biology of polluted waters. Liverpool, $202 \mathrm{pp}$.

Jerlov, N. G., 1953. Particle distribution in the ocean. Rep. Swed. deep Sea Exped. 3 (3), $71-97$.

LAAKso, M., 1965. The bottom fauna in the surroundings of Helsinki. Ann. zool. fenn. 2, $18-37$.

Molander, A. R., 1928. Animal communities on soft bottom areas in the Gullmar Fjord. (Kristinebergs Zoologiska Station, 1877-1927.) SkrSer. K. svenska VetenskAkad 2, 1-90.

- 1962. Studies of the fauna in the fjords of Bohuslän with reference to the distribution of different associations. Ark. Zool. 15, 1-64.

NAIR, N. B., 1962. Ecology of marine fouling and wood-boring organisms of western Norway. Sarsia 8, 1-88.

PEARson, E. A. (Ed.), 1960. Proceedings of the 1st International Conference on waste disposal in the marine environment. Pergamon Press, Oxford, $569 \mathrm{pp}$.

ReIsH, D. J., 1963. A quantitative study of the benthic polychaetous annelids of Bahia de San Quentin, Baja California. Pacif. Nat. 3 (14), 399-436.

SmidT, D. L. P., 1944. Biological studies of the invertebrate fauna of the harbour of Copenhagen. Vidensk. Medd. dansk naturh. Foren. 107.

Tulkкr, P., 1964. Bottom fauna of the polluted harbour area of Turku. (Studies on the bottom fauna of the Finnish south-western archipelago. II.) Arch. Soc. zool.-bot. fenn. 'Vanamo' 18, 175-188.

\section{Discussion following the paper by TULKKI}

PEARSON: You said that in the lower Göta river region, the amount of particulate matter in the water was higher than elsewhere, and that the number of different species found was large. Were the number of filter-feeding species found here higher than the number found further out in the fjord, and how do these numbers compare with those of burrowing animals in this area?

TULKKI: Yes, the highest densities and biomasses of filter feeding animals like Mya arenaria and Cardium lamarcki were found in the area having the largest amounts of suspended particles in the water. In the same area Capitella capitata had its maximum occurrence too. 